Available online at GSC Online Press Directory

GSC Biological and Pharmaceutical Sciences

e-ISSN: 2581-3250, CODEN (USA): GBPSC2

Journal homepage: https://www.gsconlinepress.com/journals/gscbps

(RESEARCH ARTICLE)

\title{
Investigating the diversity of endophytic fungi colonizing leaves of three species of mangroves in Corentyne, Berbice, Guyana
}

\author{
Vashti D. Sital, Phillip N.B. Da Silva* and Ferial Pestano \\ Division of Natural Sciences, University of Guyana, Berbice Campus, Tain,Corentyne, Guyana.
}

Publication history: Received on 19 December 2020; revised on 27 December 2020; accepted on 29 December 2020

Article DOI: https://doi.org/10.30574/gscbps.2020.13.3.0411

\begin{abstract}
Endophytic fungi are those that colonize the living tissues of plants without causing any disease symptoms. As colonisers of different parts and species of plants, they offer protection to the plant against herbivore and insect pest damages while also producing secondary metabolites which can be used in biotechnological processes. The aim of this study was to investigate the diversity of endophytic fungi colonizing the leaves of the Avicenna germinans (Black mangrove), Rhizophora mangle (red mangrove) and Laguncularia racemosa (white mangrove), from Palmyra, Bush Lot Beach and Wellington Park Beach, Corentyne, Berbice, Guyana South America.

A total of 303 isolates were obtained from this study. These isolates were classified into 18 species and 9 genera. The 18 species obtained are Aspergillus calidoustus, A. flavus, A. fumigatus, A. luchuensis, A. nidulans, A. niger, A. terreus. Aspergillus spp., Alternaria spp., Candida krusei, Cladosporium spp., Curvurlaria spp., Fusarium spp., Penicillium spp., Penicillium chrysogenum, Penicillium citrinum, Pythopthora spp., and Rhizopus spp. Based on the Shannon Weiner Diversity Index (H') calculation, Avicenna germinans was found to have the greatest species diversity followed by Rhizophora mangle and then Laguncularia racemosa.
\end{abstract}

Aspergillus was found to be the most dominant genus of all isolates with A. niger and A. flavus being the most common species among all three species of mangroves.

Keywords: Endophytic Fungi; Mangrove; Guyana

\section{Introduction}

Fungi are a kingdom of multicellular and unicellular organisms that are found in a variety of habitats ranging from water, plants, animals, and soil [1]. They are considered epiphytes if they occur on the surface of plants and endophytes if they occur within the tissues [2]. Epiphytes or epiphytic fungi may be resident or casual. Resident epiphytes are those which can multiply and grow on the surface of healthy leaves without making any adverse effect to the host, while casual epiphytes occur on the healthy leaf surface in the form of spores and mycelia, but cannot grow like residents. Endophytes or endophytic fungi are those that invade the tissues of plants during their life cycle without causing disease symptoms [3].

Endophytic fungi are important in biotechnological processes, since they are known for producing a high diversity of substances with potential medical, agricultural, and industrial application [3] [4]. They have a rich source of secondary metabolites which act as biologically active agents in higher plants. Derivatives from these fungi play vital roles in

\footnotetext{
${ }^{*}$ Corresponding author: Phillip N.B. Da Silva

University of Guyana, Division of Natural Sciences, Department of Biology, Tain, Corentyne, Guyana.

E-mail address: phillip.dasilva@uog.edu.gy

Copyright (C) 2020 Author(s) retain the copyright of this article. This article is published under the terms of the Creative Commons Attribution Liscense 4.0.
} 
human life and their compounds are the basis of drugs for cancer, microbial and viral diseases. The natural compounds of the endophytes act as growth inhibitors of plant pathogens [5].

According to the reported results of previous fungal surveys, endophytic colonization of terrestrial plants by fungi is ubiquitous. They are known to occur in herbaceous plants growing in tropical, temperate and boreal forests from various habitats. These habitats include extreme arctic, alpine, and xeric environments, and from mesic temperate and tropical forests. Additionally, they occur in mosses, hepatics, ferns, fern allies, and numerous angiosperms and gymnosperms, including tropical palms, broad leaf trees, estuarine trees, and diverse herbaceous annuals and many deciduous and evergreen perennials [6].

Mangroves serve as host plants for many species of endophytic fungi and the colonization of these fungi varies not only with different parts of the plant but also seasonally and with the age of the plant [7]. There are three main species of mangroves in Guyana [8] [9]. However, there is no record of study of the relationship between endophytic fungi and mangrove plants from Guyana. In view of the absence of such records in Guyana, this study sought to investigate and determine the diversity of endophytic fungi colonizing the leaves of the Avicennia germinans, Laguncularia racemosa and Rhizophora mangle, in Corentyne-Berbice, Guyana, South America.

\section{Material and methods}

\subsection{Site of work}

This research was carried out at three different locations along the Corentyne coast, Berbice. These locations include the mangrove forest at Palmyra, Bush Lot Beach, and Wellington Park Beach.

\subsection{Materials}

Plastic bags, leaf samples, agar powder, petri plates, $70 \%$ ethanol, sodium hypochlorite, slides, methylene blue, dissecting microscope, potato, dextrose, chloramphenicol.

\subsection{Sampling Method, Collection and Storage of Leaf samples}

Random sampling was used to collect leaves from the L. racemosa and A. germinans from Wellington Park and Bush Lot mangrove forests, and $R$. mangle at Palmyra mangrove forest. Each site was sampled three times. Ten leaves were collected each time for each species of mangrove at the different locations. The leaves were placed in plastic bags, labelled according to species and location and then taken to the laboratory for processing. At the laboratory, they were stored at room temperature for less than twenty-four hours.

\subsection{Isolation of endophytic fungi from leaves}

The leaves were thoroughly washed under running water and $1 \mathrm{~cm}^{2}$ was teased off from each leaf base. The leaf fragments were sterilized in 70\% ethanol for 5 seconds and then submerged in sodium hypochlorite for 90 seconds [3]. The leaf fragments were then placed into the medium which was composed of Potato Dextrose Agar and amoxicillin. The inoculums were then incubated at room temperature [10]. The cultures were examined daily and observations were recorded. Colonies were identified based on colony morphology, colour, hyphal structures, and/or spores [3] [11] [12].

\section{Results and discussion}

The aim of this study was to determine and compare the diversity of endophytic fungi colonizing the leaves of $A$. germinans, L. racemosa and R. mangle from Corentyne, Berbice, Guyana. The mangrove forest located at Wellington Park Beach, Bush Lot Beach and Palmyra were sampled three times and ten leaf samples were collected each time. Leaves for the A. germinans, L. racemosa were collected from the mangrove forests at Wellington Park and Bush Lot, while leaves from the R. mangle were collected from Palmyra; since these species where found at those specific areas. A total of 150 plates were inoculated and 18 fungal species were obtained belonging to nine genera.

Among the three species of mangroves samples, Avicennia germinans was found to have the greatest species diversity as compared to the other two species of mangroves; however, based on the significance calculated in excel the three species of mangroves were not found to be significantly different from each other. 
Table 1 Isolates obtained from the mangrove forest located at Wellington Park Village

\begin{tabular}{|l|l|l|}
\hline Species of mangrove & Trial & Fungal isolates obtained \\
\hline $\begin{array}{l}\text { Laguncularia racemosa } \\
\text { (White) }\end{array}$ & 1 & $\begin{array}{l}\text { Aspergillus niger } \\
\text { Aspergillus spp. } \\
\text { Fusarium spp. } \\
\text { Penicillium citrinum }\end{array}$ \\
\hline & 2 & $\begin{array}{l}\text { Aspergillus niger } \\
\text { Penicillium citrinum } \\
\text { Penicillium spp. } \\
\text { Candida krusei }\end{array}$ \\
\hline & 3 & $\begin{array}{l}\text { Candida krusei } \\
\text { Fusarium spp. } \\
\text { Penicillium citrinum } \\
\text { Penicillium spp. }\end{array}$ \\
\hline
\end{tabular}

From Table 2, it can be seen that six different species of fungi were isolated from the leaves of the white mangroves of the Wellington Park mangrove forest. A total of four (4) species were obtained from each trial; however, the diversity varies. Trial 1 yielded Aspergillus niger, Aspergillus spp., Fusarium spp., and Penicillium citrinum, trial 2 yielded Aspergillus niger, Penicillium citrinum, Penicillium spp. and Candida krusei while trial 3 yielded Fusarium spp., Penicillium citrinum, Penicillium spp. and Candida krusei

Table 2 Isolates obtained from the mangrove forest located at Bush Lot Village

\begin{tabular}{|c|c|c|}
\hline Species of mangrove & Trial & Fungal isolates obtained \\
\hline \multirow[t]{3}{*}{$\begin{array}{l}\text { Avicennia germinans } \\
\text { (Black) }\end{array}$} & 1 & $\begin{array}{l}\text { Aspergillus fumigatus } \\
\text { Aspergillus niger } \\
\text { Penicillium chrysogenum }\end{array}$ \\
\hline & 2 & $\begin{array}{l}\text { Aspergillus fumigatus } \\
\text { Penicillium chrysogenum }\end{array}$ \\
\hline & 3 & $\begin{array}{l}\text { Aspergillus fumigatus } \\
\text { Aspergillus niger } \\
\text { Penicillium chrysogenum }\end{array}$ \\
\hline \multirow[t]{3}{*}{$\begin{array}{l}\text { Laguncularia racemosa } \\
\text { (White) }\end{array}$} & 1 & $\begin{array}{l}\text { Aspergillus calidoustus } \\
\text { Aspergillus fumigatus } \\
\text { Aspergillus niger } \\
\text { Candida krusei } \\
\text { Curvularia spp. }\end{array}$ \\
\hline & 2 & $\begin{array}{l}\text { Aspergillus niger } \\
\text { Candida krusei } \\
\text { Curvularia spp. } \\
\text { Rhizopus spp. }\end{array}$ \\
\hline & 3 & $\begin{array}{l}\text { Aspergillus calidoustus } \\
\text { Aspergillus fumigatus } \\
\text { Rhizopus spp }\end{array}$ \\
\hline
\end{tabular}


A total of three species of endophytic fungi were obtained from the leaves of the black mangrove at Bush Lot Beach (Table 2). From trial 1 three species were obtained; Aspergillus fumigatus, Aspergillus niger and Aspergillus chrysogenum. From trial 2 Aspergillus fumigatus and Aspergillus chrysogenum were obtained, while trial 3 yielded Aspergillus fumigatus, Aspergillus niger, and Aspergillus chrysogenum. Additonally, five species of endophytic fungi were obtained from the leaves of the white mangrove from Bush Lot Beach. Trial 1 yielded five species; Aspergillus calidoustus, Aspergillus fumigatus, Aspergillus niger, Candida krusei and Curvularia spp.. Trial 2 yielded Aspergillus niger, Candida krusei, Curvurlaria spp. and Rhizopus spp.. Aspergillus calidoustus, Aspergillus fumigatus and Rhizopus spp. were obtained from trial 3.

Table 3 Isolates obtained from the mangrove forest located at Palmyra

\begin{tabular}{|l|l|l|}
\hline Species of mangrove & Trial & Fungal isolates obtained \\
\hline $\begin{array}{l}\text { Rhizophora mangle } \\
\text { (Red) }\end{array}$ & 1 & $\begin{array}{l}\text { Aspergillus flavus } \\
\text { Aspergillus fumigatus } \\
\text { Aspergillus niger } \\
\text { Cladosporium spp. } \\
\text { Rhizopus spp. }\end{array}$ \\
\hline & 2 & $\begin{array}{l}\text { Aspergillus flavus } \\
\text { Aspergillus niger } \\
\text { Cladosporium } \\
\text { Rhizopus spp. }\end{array}$ \\
\hline & & $\begin{array}{l}\text { Aspergillus flavus } \\
\text { Aspergillus fumigatus } \\
\text { Cladosporium spp. } \\
\text { Rhizopus spp. }\end{array}$ \\
\hline
\end{tabular}

The results in Table 3 show that a total of five species of endophytic fungi were obtained from the leaves of the red mangrove from the Palmyra mangrove forest. Trial 1 yielded five species; Aspergillus flavus, Aspergillus fumigatus, Aspergillus niger, Cladosporium spp. and Rhizopus spp.. Trial 2 yielded Aspergillus flavus, Aspergillus niger, Cladosporium spp. and Rhizopus spp, while trial 3 yielded Aspergillus flavus, Aspergillus fumigatus, Cladosporium spp. and Rhizopus spp.

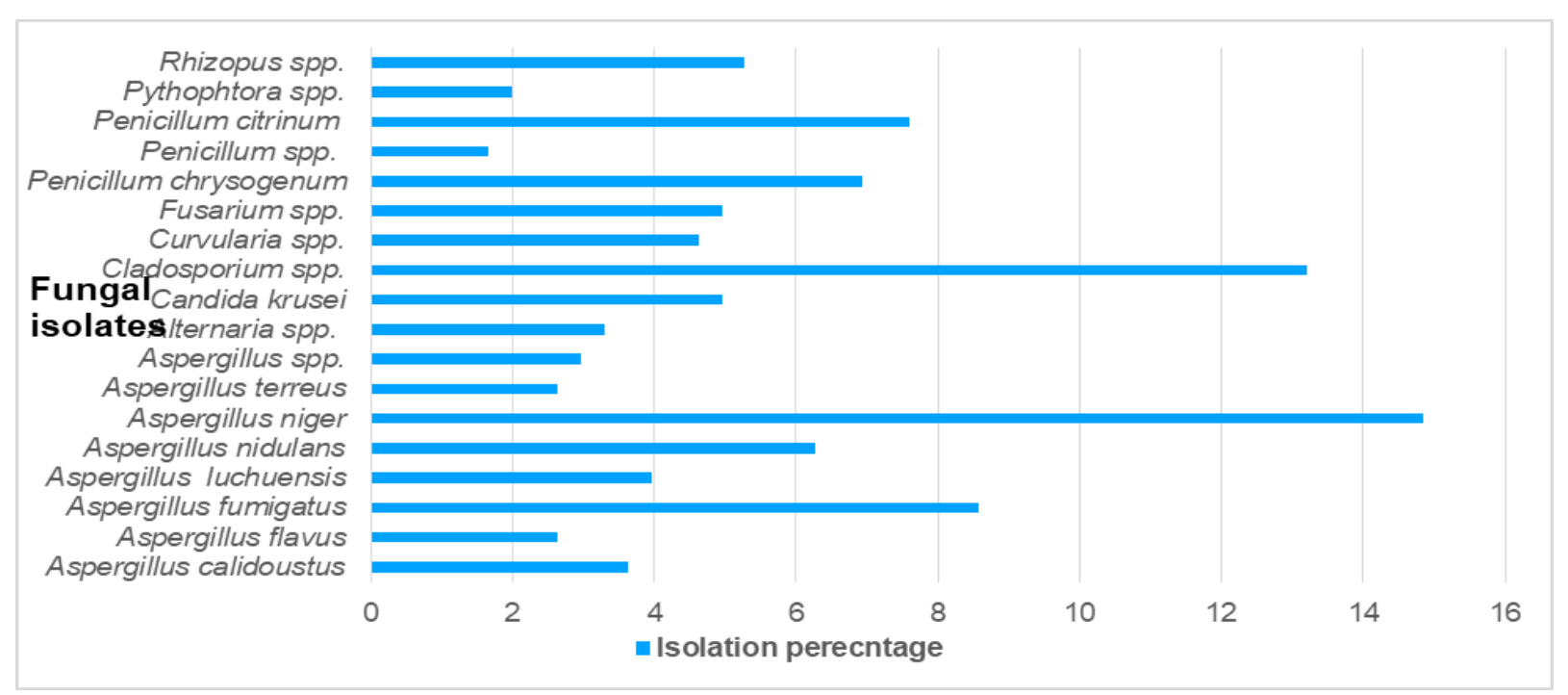

Figure 1 Isolation percentage for the fungal isolates obtained from the three species of mangrove

Figure 1 shows that among the total number of isolates obtained, Aspergillus niger was the most abundant species of 45 colonies (14.8514\%), followed by 40 (13.2013\%) Cladosporium spp. 40 colonies (13.2013\%), Aspergillus fumigatus 26 colonies (8.580\%), Penicillum citrinum 23 colonies (7.590\%), Penicillum chrysogenum 6 colonies (1.980\%), 
Aspergillus nidulans 19 colonies (6.270\%), Rhizopus spp. 16 colonies (5.280\%), Candida krusei 15 colonies (4.950\%), Fusarium spp. 15 colonies (4.950\%), Curvularia spp. 14 colonies (4.620\%) , Aspergillus luchuensis 12 colonies (3.960\%), Aspergillus calidoustus 11 colonies (3.630\%), Alternaria spp. 10 colonies (3.300\%), Aspergillus spp. 9 colonies (2.970\%), Aspergillus flavus 8 colonies (2.640\%), Aspergillus terreus 8 colonies (2.640\%), and Pythophtora spp. which was the least abundant species of 6 colonies $(1.980 \%)$.

The most dominant species obtained was the Aspergillus niger. This was expected since it is a cosmopolitan species which has a very fast growth rate and high tolerance to $\mathrm{pH}$ [13]. On the other hand, Pythophtora spp. was the least dominant because even though they are distributed worldwide, most species are restricted to specific regions [14].

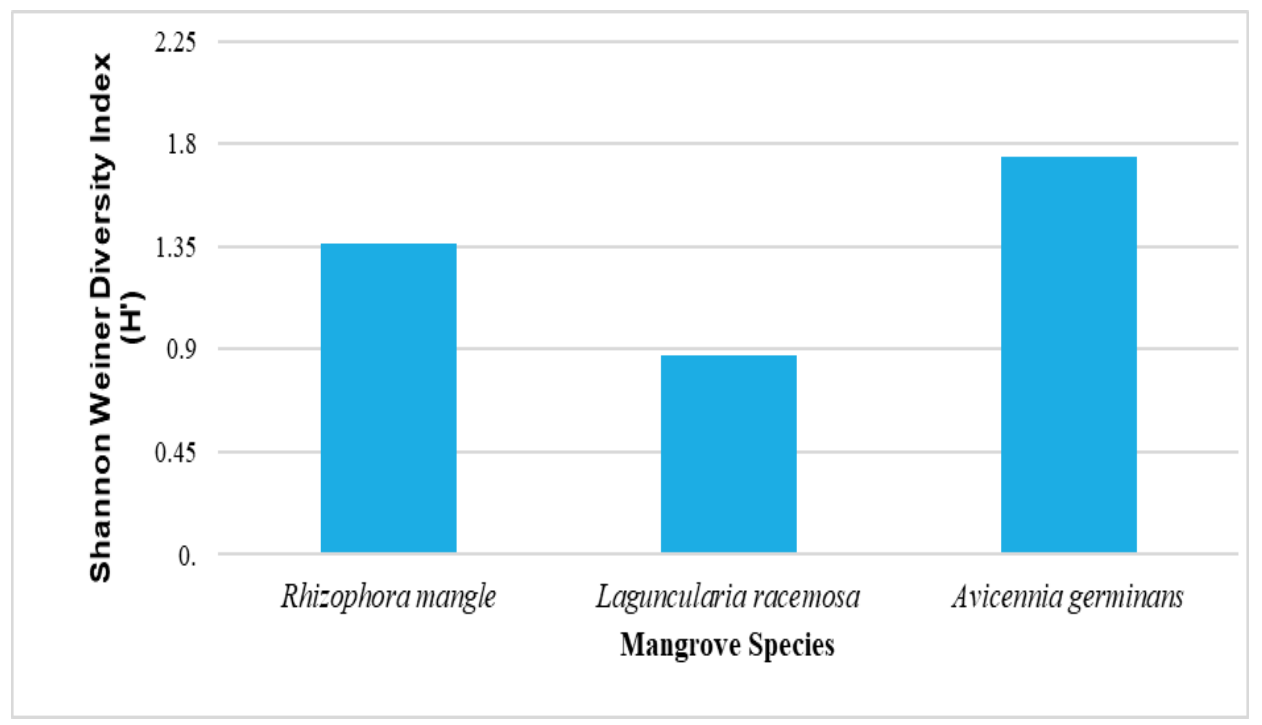

Figure 2 Diversity of the three species of mangrove.

Shannon Wiener Diversity Index ( $\left.\mathrm{H}^{\prime}\right)$ depicts the diversity of the community and takes into consideration species richness and abundance [15]. According to [16], the ( $\left.\mathrm{H}^{\prime}\right)$ value in most ecological studies is rarely above 4 and is most times between 1.5 to 3.5. Additionally, as the H' value increases so does the species richness and evenness of the community. Figure 2 illustrates the ( $\left.H^{\prime}\right)$ value which was calculated in excel for the three species of mangroves. It can be seen that the A. germinans has an $\mathrm{H}$ 'value of 1.744376681 which makes it more diverse when compared to the other two species. $R$. mangle had the second highest H 'value of 1.360140424 , followed by L. racemosa which was the least diverse species having an $\mathrm{H}$ 'value of 0.871230054 .

Table 4 Anova table for the three mangrove species based on the isolates obtained

\begin{tabular}{|l|l|l|l|l|}
\hline Source of variable & $\boldsymbol{F}$ & $\boldsymbol{p}$-value & $\boldsymbol{F}$ crit & Significance \\
\hline Species of isolates & 14.13448153 & $2.74977 \mathrm{E} 11$ & 1.898622 & Not significant \\
\hline Species of mangroves & 2.145321485 & 0.1317557 & 3.259446 & Not significant \\
\hline
\end{tabular}

An Anova (Table 4) was done to determine how significantly different the three mangrove species were from each other based on the species of the isolates obtained. According to [17], statistical significance is the likelihood that a relationship between two or more variables is caused by something other than chance. Statistical hypothesis testing is used to determine whether the result of a data set is statistically significant by providing a p-value. This p-value represents the probability that random chance could explain the result. In general, a p-value $>=5 \%$ or 0.05 is statistically significant.

The results in Table 4 show that the p-values are all greater than $0.05 / 5 \%$. This means that the fungal isolates obtained from the three mangroves species are not significantly different from each other. 


\section{Conclusion}

This study investigated the diversity of endophytic fungi colonizing the leaves of Rhizophora mangle, Laguncularia racemosa, and Avicennia germinans from three different locations in Region six, Corentyne, Berbice. Isolates from all three species of mangrove had endophytic fungi. Eighteen (18) species of endophytic fungi were obtained; Aspergillus calidoustus, Aspergillus flavus, Aspergillus luchuensis, Aspergillus nidulans, Aspergillus nidulans, Aspergillus niger, Aspergillus terreus, Aspergillus spp., Alternaria spp., Candida krusei, Cladosporium spp., Curvurlaria spp., Fusarium spp., Penicillum chrysogenum, Penicillum citrinum, Penicillum spp., Pythophtora spp., and Rhizopus spp. Among the three species of mangroves sampled, Laguncularia racemosa was found to be the most diverse, followed by Rhizophora mangle and then Avicennia germinans which was the least diverse species. However, Avicennia germinans was found to have the highest species richness, followed by Laguncularia racemosa, and Rhizophora mangle which had the lowest species richness. Additionally, Aspergillus niger was the most abundant species, followed by Cladosporium spp., Aspergillus fumigatus, Penicillum citrinum, Penicillum chrysogenum, Aspergillus nidulans, Rhizopus spp., Candida krusei, Fusarium spp., Curvularia spp., Aspergillus luchuensis, Aspergillus calidoustus, Aspergillus spp., Alternaria spp., Aspergillus flavus, Aspergillus terreus, and Pythophtora spp. Finally, based on the isolates obtained the three mangrove species were not significantly different from each other since the p-value calculated was 0.1317557 .

\section{Compliance with ethical standards}

\section{Acknowledgments}

The authors express gratitude to the staff of the Biology Department at the John's Science Centre, University of Guyana, Berbice Campus, Tain, Guyana, South America.

\section{Disclosure of conflict of interest}

The authors hereby declare that this manuscript does not have any conflict of interest.

\section{References}

[1] Paul, N. C., \& Yu, S. H. (2018). Microbiology. Retrieved from microbiology,or,kr: https://www.ncbi.nlm.nih.gov/pmc/articles/PMC3755197

[2] Osono T. Diversity and Ecology of Endophytic and Epiphytic Fungi of Tree Leaves in Japan. A Review. In: Verma V., Gange A. (eds) Advances in Endophytic Research. 2014. Springer, New Delhi. https://doi.org/10.1007/97881-322-1575-2 1

[3] Cavalcanti AM, Costa IP, Maria CL. Diversity of Leaf Endophytic Fungi in Mangrove Plants of Northeast Brazil. Brazilian Journal of Microbiology. 2012; 1165-1173.

[4] Salini G, Madhusoodhanan A, Joseph A, Mohan A, Navya RK, Nair AV. Antibacterial and antioxidant potential of endophytic fungi isolated from mangroves. Der Pharmacia Lettre. 2015; 53-57.

[5] Baskar S. Biological Properties of Endophytic Fungi. Retrieved from Biological and Applies Sciences. 2016.

[6] Polishook, D. J. (2004). Endophytic Fungi. Retrieved from Research Gate: https://www.researchgate.net/profile/James_White15/publication/233819538_Endophytic_fungi/links/09e4 150e9b1fe80567000000/Endophytic-fungi.pdf

[7] Liu, A. R. (2007). Research advances in endophytic fungi of mangroves. Retrieved from PubMed: https://www.ncib.nlm.nih.gov/m/pubmed/17615839

[8] Bovel, 0. (2011). Species Used for Mangrove Restoration in Guyana. Retrieved from Guyana Mangrove Nursery Manual: http://www.gcca.eu/sites/default/files/catherine.paul/guyana_mangrove_nursery_manual_

[9] Evans, J. I. (1998). The Restoration of Mangrove Along the Costal Belt of Guyana. Retrieved from Mangrovesgy.org: http://www.mangrovesgy.org/home/images/stories/Documents/Restoration\%20of\%20mangroves Evans.pd $\underline{\mathrm{f}}$

[10] Madavasamy S. Isolation, identification of fungi from Avicinnia marina Muthupet mangroves Thiruvarur Dt. Asian Journal of Plant Science and Research. 2012; 452-456. 
[11] Mailafia S, Olabode KO, Osanupin R. Isolation and identification of fungi associated with spoilt fruits vended in Gwagwalada market, Abuja, Nigeria. 2017.

[12] Phyo KN, Phay Suto M, Ando K. Isolation and Identification of Mangrove Fungus from Bruguiera sexangula (Lour.) Poir. Universities Research Journal. 1994; 4: 276-278.

[13] Gutham AK, Sharma S, Avasthi S, Bhadauria R. Diversity, Pathogenicity and Toxicology of A. niger: An Important Spoilage Fungi. Research Journal of. 2011; 70-280.

[14] Barry. (2019). The Gymnosperm Database. Retrieved from https://www.conifers.org/topics/phytophthora.php

[15] Pielou C. Ecological Diversity. New York: Wiley Intescience Publication. 1975.

[16] Kerkhoff. (2010). Measuring Biodiversity of Ecological Communities. Retrieved from http://biology.kenyon.edu/courses/.bio1229/diversity.pdf

[17] Kenton, W. (2019). Statistical Significance. Retrieved from Investopedia: https://www.investopedia.com/terms/s/statistically_significant.asp 